\title{
ROMA HUKUKUNDA ALIM SATIM AKTINDE HASARIN INTIKALI
}

\author{
Dr. Kudnet AYITER \\ Roma Hukuku Doçenti
}

I. Roma hukukunda *Periculum* sözü ile jfade edilen mefhum hukukumuza «hasa $\gg$ şeklinde geçmiştir. Periculum menşe itibariyle latincede kendisiyle tecrübe yapılan şey», «deneme» «deneme yaz]s]» ma nâlarına geliyordu. Sonraları *risk», etehlike», «hasar, ve hatta «dâva , "dâva erilmek», «batma tehlíkesi» mânala :ma da kullanılmıştır. (Georges, Lateinisch - Deutsches Handwörterbuch, cilt II, s, 1601, 1602). Pe riculum terimi esas ittibariyle umulmıyan hal sebebiyle edanın inkânsız hale gelmesünde kullanilır. Eda, umulmiyan bir halden dolayı veya sath. cının kusuru olmadan malın telef olması yahut durumunun fenalaşma. sI sebebiyle artık tamamen veya kısmen yerine getirilemezse bâyi seme ni müşteriden istiyebilecek midir yoksa istiyemiyecek midir? Hasar'in aidiyeti meselesi, yani müş̧teriye veya bâyiye ait olması meselesi bu suale müspet veya menfi cevap verilmesine bağlıdı. Eğer müşteri semeni ödiyecekse hasarın müşte:iye ait olduğınu, ödemiyecekse bâyiye ait ol duğunu söyleriz.

Türk Borçlar Kanunu Hasar ile ílgili şu hükümleri ihtivva eder:

Borclar Kanunu 183. Nefi ve Hasar - Halin icabindan veya husust şartlardan mütevellit istisnaların maadasında, satılan şeyin nefi ve hasa:1 akdin inikadı anından itibaren alıcıya intikal eder.

Bununla beraber yalnız nev'en tayin edilmiş olan satılanın ayırt edil miş olması da lâzımdır ve başka bir yere gönder:lecek ise satıı bu maksatla satılan üzerinden yedini refetmiş bulunması da şarttır.

Borçlar Kanunu 117. Ifanın mümkün olmamas 1 - Borçluya isnat olu namıan halle: münasebetiyle borcun ifası mümkün olmazsa, borç saki. olur.

(Son fikra) Kanun veya akid ile borcun ifasından evvel bile vukua gelen zararın, alacaklıya tahmil edilmiş olduğu haller bundan müstesnadir. 
Borçlar Kanunu 216. Menfaat ve muhatara (Gayrimenkullerde) Satılanın alıcı tarafından kabzedilmesi igin mukavele dik buir müddet toyin edildiği halde onun nefi ve hasarınin alıcıya intikal etmemesi asıldır.

Borçlar Kanunu 210. Semene istihkak ve semenin faizi - Hilaf: na mukavele mevout değil ise, satılan ahconm yedine girince satıcı semene müstahak olur.

Sarahatle görüldüğü gibi Borçlar Kanununumuzda hasar hakkandaki hükümler nev'en muayyen mal bo:çlarına tatbik edilemez. Nev'en muayyen bir malın borçlusu, malın hasa: görmesi halinde aynı neviden başka mal bulup vermek mecburiyetindedir. Hasar görmüş _malı teslim etmesi halinde mukavelede tesbit edilmiş cinsten mal vermemiş olaca. ğından borcunu yerine getirmiş sayılmaz. Şu kadar kı nev'en muayyen malm ayırt edilmiş olması veya sevkedilmiş olması halinde, nev'i ile muayyen borç mahiyeti bir dereceye kadar kaybolacağmndan, hasarın müssteriye intikalinden bahsedilebilir.

Dikkat edilirse, Kanun Gayrımenkôller hakkında B. K. 183 deki hïkmüi her zaman tatbik etmemektedir. Gayrnmenkulïn muayyen bir müd. det ivginde kabzedilmesi kararlaştırimışsa o müddet içinde satıcının har sardan mes'ul olacağı ka arlaştırılmıştır.

Hasar probleminin yaln1z tasarruf ve taahhüt muamelelerinin tefrik edildiği bir hukuk nizamında mevzubahis olabileceği de şüph heden âri dîr. Bugünkü Fransız Hukukunda (Code Civil 1138) oldugu gibi taahhia: ve tasarruf muamelelerinin tefrik edilmediği ve satışta, satı̧ aktinin yapılması ile mülkiyetin geçt ği bi: hukuk sisteminde hasarın kime ait ol duğundan bahsetmeğe imkần yoktu:, zira pek tabiî olarak mâlike ait olur. (Tasarruf ve taahhüt muameleleri tefriki için X. Ayiter, Meden $\mathbf{H u}$. kukta tasarruf muameleleri, Ankara 1953 kitabina bakınız.) Roma Hukuku da borç aktini - alım satım aktini — yalnız taahhüit muamelesi olarak kabul ediyo: ve mülkiyetin intikalini temin edecek olan teslim (traditio) muamelesini ondan tefrik ediyordu.

II. 14 Mayıs 1948 günü o zamanlar İstanbul Hukuk Fakültesi Roma. Hukuku ve Medenî Hukuk Ord. Profesörüi olan Andreas B. Schwarz, Ankara Hukuk Fakültesinin ik.nci sınıfında verdigi bir derste, Türk Medenî Kanununun 183 üncii maddesinde ifadesini bulmuş olan enefi ve hasar. akdin inikadından it:baren alıcıya intikal eder, hïkmünü tenkit etmiş, bu hükmün bir çok bakımlardan adâlete aykırı olduğunu belirttikten sonra, Borçlar Kanunưnun bu işle ilgili hükümleri sahasında umumâ bir ilmî münakaşa açılmasını temenni etmişti (1). Çok sarỉ görünen kanun hü-

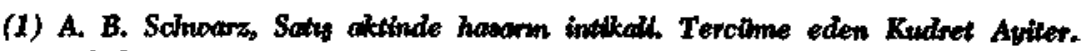
Ankana Huktk Fakilteat Dergisi. Cal IV. Yd 1948. Sayfa 159 - 167. 
kümlerine rağmẹn, yepyeni bir fikri büyük bir maharet ve cesaretle o: taya atan Profesör Schwarz'ın bu dersi Ankara Hukuk Fakültesi hocalarının hemen hemen hepsi tarafından hayranlıkla dinlenmişti. Profesör Schwarz'ın fikirleri şu şekilde bir araya toplanabilir:

«Corpus İuris Civilis'te karşmıza çlkan «periculum ad emptorem pertinet veya *periculum emptoris est» hükmï modern kanunlaştırmaların çoğu tarafından kabul edilmem:ştir. Avustu:ya ve AIman Medenì Kanunu hasarın teslim anına kadar satıcıya ait olacağını kabul etmiştir. Fransız Medenî Kanunu her ne kadar Roma Hukukunun prensibine băg $h_{1}$ kalmıs görünüyorsa da orada mülkiyet aktn in'ikadı ile intikal etti. ğine göre hasarın müşteriye ait olmayıp mâlike ait olduğu söylenebili:. İsviçre Borçlar Kanunu (Mad. 185) ise Roma Hukukunun prensibini kabul etmiş ve bir taraftan mülkiyetin teslimle, diğer taraftan hasarın satı̧ aktinin in'ikadı ile intikal edeceğini ifade etmiştir. Roma Hukukunda mülkiyetin intikali teslimle oluyordu. Iustinianus Hukukunda karşımıza çlkan epericulum est emptoris» kaidesinin klâsik hukuka ait olup olmaölğı ise çok münakaşa edilmiştir. Muhtemelen klâsik hukuka aittír ve alım satım aktinin mutlaka peşin para ile yapıldığı devirlerden kalmadır (2). Roma Hukukunda hakikî vaziyetin tesbiti bugünkỉ durumu daha salimen tetkik etmemize de yardım edecektir. Bo.çlar Kanununun 18i üncï maddesi yanında bu mesele ile ilgili 210 uncu maddeyi görüyoruz. Bu maddeye göre «Hïlâfina mukavele mevcut değilse meb'i müşterinin ye dine girince bâyi semene müstahak olur».

O halde müşteri ancak meb'iin tesliminden sonra semeni ödiyecektir. Mevcut kanaata göre bunun tek istisnası 183 üncü maddedir. Bu ise mânasız bir hükümdür. Ancak, Borçlar Kanunu 210 uncu maddesinin hilâa fına bir akilt yapılmış olup da, bu maddenin tatbilk edilmemesii kararlaş tırılı:sa o vakit 183 üncü maddenin tatbiki yelinde olur. Kaldı ki diğer tarafta mïhim bir problem 210 uncu maddedeki münasebetin yalnız bir defiye mi imkân verdiği veya esasa ait bir mesele ola:ak hâkim tarafindan resen nazan itibare alınması mi gerektiği meselesidir. Von Tuhr burada bir def'inin değil hâkim tarafından resen nazarı itibare alına cak bì: vaziyet:n bulunduğu kanaatındadır ve bu doğrudur. Bu durumda hasar, yalnız peşin para ile yapılan satışlarda Borçlar Kanunu 183 gereğince, diğer hallerde ise ancak teslim ile müşteriye intikal edecektir. Zaten 183 üncui madde shususî hallerdeki istisnaları maddenin şumulii dışında tutmuştur. Bu hükümden de istiffade edilip yukardaki hüküm tak. viye edilebili:. Her halde hâkim serbest hareket ederek mânasız bir hïkmü ihtiyaca uygurs hale sokmaltdrr.,

(2) Schwarta, a. a. vazis, a. 164. 
III. Son derece alâka çekici olan bu fikirlerden sonra Profesör Schwarz'in arzu ett' ği ilmî münakaşa olmamiş, büyük bìr ihtiyaçtan doğan prablem ele alınmamıştır. Esat Arsebük'ün aynı sene sonunda çıan $* \mathrm{Hu}$. susî Akit Tipleri» yazısında (3) 87 ilâ 141 de Satış akti et:aflıca incelendiği halde bu probleme hiç temas edilmemis, Zerrin Akgün'ün 1953 yl. linda çlkan iki yazısı *Menkul Bey'inde Hasar» (4) ve *Gayrımenkul satış vaadi. ve gayrımenkûl bey'inde hasar (5) meselenin yukarda temas edilen tarafını hiç ele almamış, ezcümle Borçlar Kanunu 210 muvacehesinde B. K. 183' ün durumunu hị incelememiştit. Zerrin Akgün'ün -Menkul beyinde hasar yazısının sonunda, Cevat Abdïrrabim Gücüi, ün, Schwarz'ınkine muvazi ve ona takaddüm eden Roma Hukuku ve. Avrupa hukuklarına dayanmadiğı halde, sırf ihtiyaç sebebiyle yaptı̆ı tenkide temas ettiği halde bu problem üzerinde - tevakkuf etmediğini görüyoruz (7). Turan Bakı: tarafindan 1954 yılında neşredilen *AImm Satım aktinde hasar problemib (8) de meseleyt bu bakimdan ele almamıs, problemin bu cihetine hiç temas etmeden kanun hïkümlerini zikr ve izah etmekle iktifa etmiştir. Bütün bu yazılarda Prof. Schwarz'ın yazısı hiç zikredilmemektedir. Hasa: Problemine tahsis ettiği ve Schwarz'in konfe:ansından daha evvel neşredilmiş olan iki yazısının binincisinde "Ticarî Bey'de. Hasar»da daha çok mücbi:" sebep, kaza meselesine temas. eden ve neticede -Hasar, âkitler arasındaki borç münasebetlerinde, ait olduğu tarafin talep hakkınin sukutunu mucip imkânsızlık» olduğunu söylijyen (10), ikinci bir yazisında «Mecellede hasar» (11) problemi ije meşgul olan Prof. Halil Arslanl, ikinci yazısında *Gerçi hasarın intika. linde teslim sisstemí müdafaa edîlebilìr. Hattâ belki modern ihtiyaç̧ara en uygun sistem teslim usulüdür. Şunu bilhassa tebarüz ettirmek isteriz. ki buradaki münakaşanın hedefi hangi sistemin elverişli olduğunu tayin

(3) Esat Arsebiik, Hususi akit thpleni. Ankara Ünideraited Hukuk Fakilleat Dergiai. Calt V. 1948, saye 1-4. s. $85-153$.

(4) M. Zerwin Akgin, Menked Bey'inde hasar. Ad. Dergisi. Yd 44. 1953. Sann 3. 8. $251 \cdot 263$.

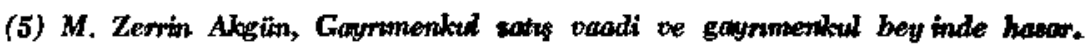
Ad. Dengisi. Yd 44. 1953. Sann 5. 8. $445-465$.

(6) Cevat Abdurrahim Giicinn, Natasi ve ameli hukuk davalan. 2 inci Kitop. is. tankul 1946. o. 542 o. $d$.

(7) Z. Akgiin, a. g. yast. s. $261-262$.

(8) Turan Bakw, Altm satsm aktiode hasar pnoblemi. Ad. Dergdes YIl 45, 1954. Sann 9. s. 1091 - 1103.

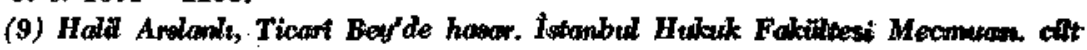
XIII. 1947. Sagn 4 s. 1451 v. $d$.

(10) H. Arslanlt, a. g. yaza. 8. 1474.

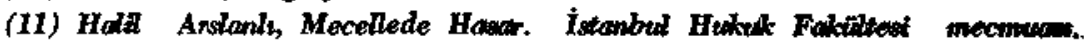
cit. XIV. 1948. Sayn 1-2. a. 248 v. $d$. 
değildir. Hasarın intikalinde akit, mülkiyet veya teslim esası kabul edil miş olabilir. Bunlardan hangisi kabul edailmiş olursa olsun terviç edilen sistem icabı mevzu hükümle: arasınnda da âhenk bulunmalıdır..» (12) şeklinde meselenin mihrak noktasını belirtiyor, fakat belki de mevzuunun yalnız Mecelle olması sebebiyle bu günkỉ hükü̈mler üzerinde fazla durmuyor. Prof. Hüseyin Avni Göktürk de 1951 senesinde neşrettiği *Borçlar Hukuku. İkinci Kısım. Aktin mubtelif nevileri` kitabında (13) meseleye yalnız kanundaki hükümlerin gösteril mesi tarzında temas etmiş, problemin en can alacak noktası olan B. K. 183 ve 210 arasindaki münasebete hiç temas etmemiş, bu iki maddenin telif :mkânlarmı da aramamış̧ır.

Profesör Sohwarz'ın yaptı̆̆ı tenkide kısa da olsa temas eden, «Borçlar Hukuku Dersleri - Hususî Borç Münasebetler:» eseri (14) ile P:ofesör Nedip Biilge olmuştu: Schwarz'ın ileri sürdüğü fikirlere yalnı işaret etmekle iktifa eden müellif (15), Hasar bakımından yaptı̆̆ tahlilde daha çok B. K. 117 le 183 a asındaki münasebet üzerìnde durmakta, $183^{3}$ ü 117 nin :Kanun veya akit ile borcun ifasindan evvel bile vukua ge len zararın, alacaklıya tahmil elilimiş olduğu baller bundan müstesnadırs hükmüne göre istisnaî hükümlerden biri olduğu net.cesine varmaktadır Borçlar Kanunu 210 ile mevcut münasebet tetkikin konusu yapılmamış. nev'en tayin edilm:ş eşya satımında ve taliki şarta bağlı akitlerde hasar p"oblemi üzerinde durulmuştur.

Prof. Şakir Berki «Borçlar Hukuku. Kitap II. Hususî Hükümler» (16) de de Bey'ide Nef'i ve Hasar bahsinde, Borçlar Kanunu 183 ün bükümlerini tekrarla yetinmiş, asıl problemin diğer maddeler ka:şısındaki duru muna temas etmemiştír.

Bu durum karşsısında Prof. Schwarz'ın ilmî bîn münakaşaya davetinirı cevapsız kaldığg söylenebilir. Kimse meselenin asl mühim cihetine temas etmemiş, problem ihtiyacı karşllyacak şekilde hal ed.Imemiş, bi: hai tarzı bulunmamıştrr. Nitekim tatbikat, Profesör Schwarz'ın hakhı olarak dediği gibi, halktan her hangi bir kimsenin, hatta her hangi bir tüccarın aklına gelmiyeceği, hakkaniyete aykırı şeklinde devam etmektedir: «Tü:-

(12) Ayni yazi. 5. 270.

(13) H. Amw Göltüurk, Bonglar Hukuku. Ikinci kstm. Aktin mudhtelif mevilert. Ankara 1951. 3. $391 \cdot 392$.

(14) Necip Bifge, Borglar Hukuku dersleri. Hutust Bars mïnasebetleri. Ankara 1958. ค. 26 겨 30.

(15) Arnt eser. 8. 29 not 3.

(16) Sakir Benki, Bonglar Hidkuku. Kitepp II. Hususi Hikiumler. Ankara I958. s. 9 - 11 . 
kiye'de, teslim edilmeden yanan bir halın!n bedeli olan 2000 lirayı talep etmek her hangi bir satıcının aklına gelir mi? Meğer ki bir hukukçı kend sine bu ẹmkânu izah etsin (17).

IV. Bu gün bu sahada yazzlan yazılarda- Adet olduğu veçhile : Ro ma Hukukundaki durum da zikrediliyor (18). Vakıa Roma Hukukunun, Kanunumuzdaki trükmün esbabt mucibesi g bi zikredildiğini ileri sü:mek istemiyorum. Fakat umumi izahat gibi anlatılsa bile bir esbabl mucibe manzarasını gösterdiğ: inkâr edilemez. Acaba bu doğru mudur? Burada - Schwarz'ın bir kaç sözünüi tekrar etmeyi faydalı buluyoruz. «Roma Hukukuna ait tetkîkler. bu günkü hususî hukukumuzun, menşei Roma Hu kuku olan kıstmlarımn anlaşılması bakımından ehemmiyetsiz değildir. Roma Hukuku aktïel bir hale, zamanin bi: meselesi haline ve kaynakları tenkit ilłminin ve tarih imminin neticeleri, zamanımı hukuku için faydalı hale getirilmelidirr. Metinlerde sonradan değişiklik yapliıp yaplmadıs̆ hakkındaki tetkikler bir fikrin klasik olmadığın, ontaya koya ssa veya $\mathrm{Bi}$ zanslılar tarafından değiştirilmiş olmasın muhtemel gösterirse ve bu fkir bu gün de yaşamlya devam ediyorsa, oraya bu günkü hukuk jçin tehlike bulundugunu bildiren, ikaz edici, bir levha koymak icap eder. Şu halde Bonçlar Kanunumuzun I83 üncii maddesindeki prensip" kendisinin hakkaniyete ve maksada tevafuk etmesi noktasindan ötedenberi cai sual görülmüşse, Roma Hukukunda yapilan yeni tarihçi tetkkklerin bu gï. ne kadar gelmiş olan telâkkileri hiç olmazsa sarsan ve bu telâkklerin ifade ettiğgi mânayı her halde başka tarafa kayduran neticeleri kả şısında hukuk tarihine dayanan sebeplerle de ikaz edici bi: levha asmak icab eder (19).

Bu tetkikimizin gayesi, menşe olarak, Rama Hukuku gösterilen Periculum est emptoris kaidesinin Roma Hukukundaki durumunu, bu ara da en yeni fikirleri bilhassa izah ederek, ksaca belirtmek, ve Prof. Schwarz’' in ile :i sürdüğü, B. K. 183' ün bú günkü tatb'katı için yeni hal tarzi. nin ne dereceye kadar Roma Hukukuna yakın düştügüi problemini incelemektir.

Günümüzün, hukuk tedrisatında en çok üzerinde durulan problemlerinden birisi Roma Hukukunun aktüel hale getirilmesidir. Roma Hukuku, bilhassa borçlar hukuku sahasında, hayatiyetini bu günkü kanunla: için. de de olduğu gib丸. muhafaza etimiştir. (20).

(17) Schtodrz, a. g, yast. 8, 163.

(18) H. Arslanls. Mecellede havar. o. 248; Z. Akgith, Merkud bey'tude havar. 9. 252; Truman_Bakw, a. 5. yara. s. 1094.

(19) Schepark, a g. yazk. A. 164.

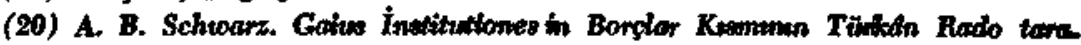

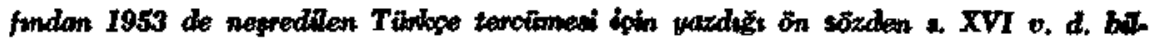
hasas a. XVII not 15. 
Roma Hukukunun gerek ilmî araştırmalarda gerek tedrisatta yen ${ }^{\mathrm{i}}$. den canlandırılması, bu günkünden daha da fazla canlandmiması, harp sonrası Avrupasında her memlekette kendisini göste :miş olan bir cereyandır. Buna sebep, son senelerde g.ttikçe kendisini daha kuvvetli göstermekte olan Hususî Hukuk bürliğine varmak temayülü, bunu hiç ol mazsa Avrupa için gerçekleştirmek arzusudur. Roma Hukukunun Avru pa'nun Hususî Hukukunda müşterek kaynak olduğu ve bu kaynağa bağ

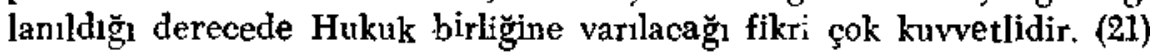

Yalnız bu arada Roma Hukukunu modern telâkkilere göre, v€ kendisine has olan bünyesi terk edilerek, bünyesine yabancr bir sistemat:ğin ışığ altında ve mefhumları kendilerine yabancl fikirle:e benzetile rek tetkik etmekten bilhassa kaçınmak icab eder. Müesseseler, mefhum lar, Roma Hukukçularının anladığı mânada tetkik edilmeli ve şüphesiz çok faydalı olan mukayeseler esnasında Roma Hukukuna bu günkü fikirlerle tesir etmeğe, onu bu günkü görüşlerimize göre izah etmeğe çalışmamalıdı?. Üzerinde durduğumuz mevzu, spericulum est emptoriss, mukayese mevzuunda hangi hududa kadar gidilebileceğin sali olabilir:

Bu günkü hukuktaki müesseseyi tetkik ederken onun kaynaklanm Roma Hukukunda buluyorsak, bugünkü hukuka has bütün düşünce tarzlarından tecerrïd ederek, Roma'da durumunun ne olduğunu aryyađağtz. Bu araştırmala:da bu günkï sistematik düşünce tarz.ımızın da tes:rí a! tında kalmamamız lâzımdır. Ezcïmle Kazuistik bir hukuk tetkïk edilirken onun bükümlerini bir sistem çinde toplamak hatahdır, zira o hukukı devrinin hukukçular öyle görmemjş, hissetmemişlerdir. Roma Hukukunda elde edilen netice müteakiben bugünkii hukuk ile karşılaştı ılabijir. Bu karşılaştırma bir taraftan müessesenin menşeini bize gösterdiği gibi çok defa bu günkü müessesenin asıl menşeinden ne kadar avrılmiş olduğunu ve bu ayrılmanın faydalı olup olmadığını tetk k etmemize de fırsat verir. Muiteakip izahat kast ettiğimizi açıkça gösterecek ve kaynağı bilmenin B. K. 183' ün mukadderatı hạkıında yapıllan bir münakașadaki ehemmiyetini belittecktir.

V. Acaba Corpus furis Civilis bize bu sahada ne gibi malzeme ve riyor.

(21) Patul Kasahaker, Europa and das römische Recht, s. 347 v. d. oe . 367 o. d.; Betti, Divitio nomano I Parte Cenerale. Prefatione, p. I. XXVIII (1935), Znoeigert, Ziele und Stoff der Juristischen - Ausbildıng, Zeit, fïr auslandisches tund inter. Privafrecht. 22 (1957) 1, 0. 8 - 9; Satellles. Le droit romain et la democratie, inder. Privatrecht. 22 (1957) 1, 8. 8-9; Salellew Le droit romain at la democratitie, Studi in onore di V. Scialoia, Il (1905) * 713 - 730 ve Salenles, L'oeutre juridique Paris 1914. s. 187 o. d. baktous. 
Roma Hukukunda alım satım akti (Emptio Venditio) iki dâva ile teç hiz edilmiştir. Bunlarn biri müşteriye tanman sactio empti. (22), diğ ri satıcnya tanınan kactio vendiltis (23) dir. Bonae fidei dâvalardan olan bu ưki dâvanin intentio'sunda "Quidquid Nm. Nm. Ao. Ao. dare facere oportet ex fide bona» şeklini görüyo.uz (D. 19, 1, 1). D 19, 1, 25 deki hükme göre borçlar aynı anda yerine getirilecek, bir tarafın borcumu yerine getirmeden yapacag talep bir exceptio ile karşllanacaktır.

D. 19, 1, 25 Iullianus, I'bro quinquagesimo quarto digestorum. Qui pendentem vindemiam emit, si uvam legere prohibeatur a venditore, advesus eum petentem p:etium exceptione uti poterit esi ea pecunia, qua de agitur, non pro ea petitur, quae venit neque tradita est.s ceterum post traditionem sive lectam uvam calcare sive mustum evehere prohibeatur, ad exhibendum vel iniuriarum age:e poterit, quemadmodum si aliam quamlibet rem suam tollere prohibeatur.

Müşteri taräfından ileri sürülebilecek olan defi «exceptio rei vendittae, sed on traditaes; satic tarafindan îleri sï:ülebilecek olan defj wo exceptio pretii nondum solutiodir (24)

Bunlar Paulus'un dedigi gibi (D. 44, 1, 7, 1) bir crei cohaerens; def olduğundan akte istinaden dâva açan herkese karşı, âkidin halıflerine karş da dermeyan edilebilir. Aktin yerine getirilmesini istiyen akt; vèya obun yerine geçinis olan kimse, her şeyden evvel kendisinin akti yerine getirdigini ispat etmege mecbu:dur. (25):

Bu hüküm esas itiblbariyle Borçlar Kanunu 210 daki hükme tekabül etmektedir. Vakıa Borçlar Kanunu 210 daki hükmün bir def'i verip ves mediły yahut hâkim tarafindan resen nazarı itibare alınacak bir vaziyet olup olmadığı uzun münakaşala:ın konusu olmuştur, fakat esạ iti. bariyle büküm aynldur. (28)

Roma Hukukunda bu sarih hükmün istisnası meblïn umulmryan bir hal sonunda telefi halinde bayinin semeni talep edebilmesidir. *Periculum est emptor's . ile ifadesini bulan bu esas, Corpus luris Civilis'in üg kitabında da tekrar tekrar ele alınmıştır. İnst. III, 23, 3; D. 18, 6, 8; Cod. 4, 49, 12. Durumu en açı âfade eden Institutiones'in metninil görelirn.

(24) Mlick, Pandektem, Eriangen 1815. call 17. s. 228 v. d. Bu terimler Kata Roma Hukuktuna ati olmamakla beraber duremu ifi ifade edigorlor. Ayme sekade, exceptio non adimpleti contractus da Pandekt htakukuntan kudlandtğ bir terimdir. Roma Hukukunda bu sahada yadna Exceptio mancis non traditae'yi göritzorus. $D$. 44, 4.5

(25) Glitck, a. g. eser. 8. 237.

(26) Schworz, a. yast, 8. 166. 
Înst. III, 23, 3. Alım satım akti tamam olur olmaz (veya söylemiş olduğumuz gibì yazısız olarak yapılmısssa, semen üzerinde mutabakat hasil olur olmaz) her ne kadar mebi (res vendita) alıcya teslim edilmemiş de olsa, mebideki hasar (periculum) derhal alıcyya geçer. Binaenaleyh, şayet satılmış köle ölmüß veya vücudunun bir tarafı zara: görmüşse, veya satılııs ev tamamen veyahut kısmen yanmışa, veya satılıı ıs arazi kısmen veyahut tamamen sel tarafından alınıp götürülmüşse, veyahut bir su baskını ile veya ağaçları söküp götüren bir firtına neticesi çok küçülmius ve degèerinden kaybetmişse, bütün bunlar, mebi eline geçmediği halde semeni tediye etmek mecburiyetinde olan alıconin zara:nnadır. Filhakika satıcl, kast (dolus) ve ihmali (culpa) olmaksızın vâki olan her şeye karşı emniyettedir. Fakat alım satımdan sonra arazi bir alluvio neticesi büyürse, bunun menfaati de alıcya. dur, zira menfaat de, hasardan mes'ul olan kimseye ait olmahdir (27).

Görüldiuğü gibi müsteri, eline hự geçmemiş olan bir mail için semeni ödemek külfeti altındadır. (28) Yukarda naklettiğimiz metin Gaius un Institutiones'inde yoktur. Kitap III 141 den sonra gelmesi icab ederdi. Corpus Iuris Civilis'de ki hüküm bu itibarla Iustinianus tarafından Institutiones'e ithal edilen hüktimle:dendir.

Alım satım aktindeki bu hükme mütenazır bir hüküm kïa aktinde D. $19,2,33$ de karşımıza çılkıyor (29).

Devlet otoruitesinin karar1 ile, istimlâk gibí hallerde, mebiin hasar görmesi halle:inde periculum est emptoris hükmünün tatbik edilmediği tahmin ediliyo: D. 19, 2, 33 teslimden evvel istimlakte, daha evvel ödenmiş olan semenin istirdat edilebleceğini, D. 21, 2, 11 pr. de ise mebin tesliminden sonra yapılan bir istimlâkte hasarnn müş̧teriye ait olduğunu ifade ediyor. (D. 18, 6, 13; D. 19, 2, 33; D. 19, 1, 13, 17; D. 10, 3, 7, 13).

Kaynakla :da hal edilmemiş olan en mühim nokta şudur:

Bâyi hasar gören veya telef olan mebi için üçüncü şahıslardan taz. minat almı̧sa, periculum est empto is hükmü acaba gene tatbik edile 8. 627.

(27) İutinianus, Inopitutiones, Tärkge metion. Ziya Umur, İstanbud. 1955. o. 129.

(28) Berger, Periculum rei vendtae. Encyclopedic dictionary of roman lavo.

(29) R. Leonhard, Emptio Venditio, RE. V 2 (1905) s. 2537 pe G. Hartmann, Juristischer Casus und seine Prdstation bei Obligationen atf Sachleistumg insbesondere beim Kauf. Jehrings Jahtbicher. Band 22. Jahr. 1884, s. 417 v. d. bithava D. $19,2,33$ igin 2.427 o. d. 
cek midir? Pandekt Hukukunda mühim münakaşalara sebebiyet vermiş olan bu mesele bilhassa bu istimlak bedellerinin bâyi tarafindan ahnma sI halinde bahse konu olmustur. Windscheid (30) burada Periculum est emptoris'in tatbik edilemiyeceği kanaatındadır.

Roma'da Res quea pondere numero mensurave constant olan esyalarda (yani tartılarak, sayılarak veya ölçülerek tesbit edilen eşalar) sa. ylmadan, tartılmadan veya ölçuilmeden satış akti tamamlanmış (emptio perfecta) sayılmazd.. Bu bakımdan bu fiiller yapilıncaya kadar satıs akti meydana gelmiş olmaz, hasar da intikal etmezdi. Ayni şekilde satıs akti nin bir şarta bağh olması halinde şartın tahakkukuna kadar akit tamam lanmıyacağına göre hasann intikalinden bahsedilemezdil. Şarta bağlı sanşlarda eşyanın telefinin satıçya, kısmen bozalmasının ise alıcıya ait olduğu hakkında Corpus Iu:is Civilis'de mevcut hüküm (D. 18,6,8) kuvvetli Interpolatio şüphesi altındadrr.

Satış aktinde bir de Custodia mes'uliyetini görüyoruz : Custodia mes'ulîyetị Klâsik Hukukda satıs aktỉnde bahse konư olan umumî mes'uliyet esası idi. Satılan malın müşte :iye devredilmesi icab ederdi. Bu, malin mahiyetine göre değişen bir hukrukî muamele şeklinde olurdu (31). Satım aktinin yapılmasindan sonra fakat eşyanin müşteriye tesliminden evvel arada geçen zaman zarfinda her türlü hirsızluktan dolayı bâyi mes'. ul addedilirdi. Klâsikten sonraki hukukta ve fustinianus Hukukunda Cus. todira mes'uliyeti kusura dayanan bir mes'uliyet haline gelmiş ve bâyi «di ligentita in custodiendos dan yani seyi hintimamla saklaması mes' uliyeti altına gìnmiştir. İşte Custodia mes'uliyetinin tatbik edildiği hallerde xpericulum est emptoris» den doğan mes'uliyetin tatbik edilmediğini götüyoruz.

Roma Hukuku kaynaklarnda *periculum est emptoris» ile ilgili ha diselerin büyük bir kısmı şarap alım satımına aittir. Bunu jzah etmek kolaydır. Şarap kolaylıkla bozulan bir eşyadır. Maddesi itibariyle bozulmya müsait bu gibi eşyalara ve bir de tabil hâdiseler ve âfetle: neticesinde eşanın hasàr görmesinde (yukarda gördü̆̆̈ïmüz gibi kölenin ölümü, yangin v. s.) «periculum est emptorissin bilhassa tatbik edildiğ açktır.

Hasarı deruhte etmis olan tarafin, buna mukabil nefi yi de alabile. ceği Roma Hukukunda kabul edilmiştir: scuius periculum eius commo.

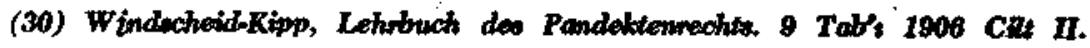
-. 390 .

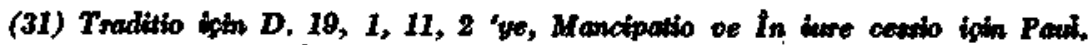
Sant 1,13 as 4 we Cafus. I. 4, 131 af ye beknes. 
dum*. Satım aktinin yaplmasindan son:a malda hasll olan ziyadeler (mahsuller) müssterinin ad edilirdi. (32).

VI. Roma Hukukunun kısaca gördüğ̈̈müz bu hükümleri öteden beri değişik şekillerde izah edilmiye çalışılmış ve pek çok nazariyelerin doğu. muna vesile teşkil etmiştir. (33)

A. Jörs (34) bunun her halde en eski alım satım aktinden bir bakiye olduğunu, çok muhtemel olarak bu satışın, Roma Hukukunda sonrala:ı karşımıza çıkan rızaî satıs aktínden ayrı olduğunu ileri sürmüş, tahminlerden pek az öteye gidebilen fikirlerinde «Periculum est emptoris, kaidesinin neden muhafaza edildiğini izah edememiştir. Iustin'anus Hukukuna kadar intikal eden bu kaideṇin asıl izaha muhtaç tarafi bu intika lin sebebi idi. Jö:s ve *Römisches Recht.» kitabının sonrak tab'larını çkartan Kunkel (35), Periculum est emptoris hükmünü ihtiva eden metinler'n esas itïbariyle interpolatio gö.mediklerini, klâs:k hukukta bu prensibjin her halde mevcut olduğunu $d_{a}$ ilâve etmisst tr. Kanaatlarına göre bu, yukarda da söylediğ'miz gibi klâsikten evvelki hukuka ait bir prensipt'i ve klâs'k hukukçular tarafından yeniden işlenmiş, $k^{1}$ șmen genlł̧letilmiş kısmen de daraltılmıştır. Ne bakımdan genişletildiği, ne bakımdan daraltıldığ hakkında en ufak bir izahat vermi yen Jörs-Kunkel'in bu fikir. le:ini etraflı şekilde incellyemiyeceğiz. Fikirlere iştírâk veya iştírâk et memek igin elmizde kâfi delil bulunmuyor.

Beseler (36) yukardaki fikre şok yaklaştı̆̆ içıı onu da burada zikretmenin uygun olacağını zän ediyoruz. Met:mlerdeki interpolatio'lan prensibin tamamen İustinianus devrinden geldiği hakkında kâf delil ad edemiyen Beseler, metinlerin değiştiridiğini kabul etmekle be:aber prensibbin klâsik hukukta da bulumması icab ett' ğjni jle:i sürmüştür. Beseler, Jörs gibi, periculum est emptoris'in menşei ile meşgul olmamakta, yalnız klâsik hukuk devrinde de mevcut olduğu kanaatını ileri sürmek tedir.

(32) Pericultan est emptoris'tn ammi hikkimleri igin Türkan Rado, Boma Hu. kuku Derderi. Borçlar Hukuku, Istambul 1956, s. 88 v. d,; Di Marzo, Roma Hukuku, Tercïme eden Ziya Umur. Istanbul I954, s. 390 v. d. Jöre - Kunkel - Wenger, Römioches Recht, 2 ve 3 tab's 141, 2 ye bakıti.

(33) Roma Huknku sahastnda problemle agit umumi bablyografya: $M$. Kons. tantinavitch, Le periculum nei venditae. There Lton, 1923; Huvelin, Revue historique de droit français et étranger, 3 (1924) 318; Ch. Appleton, Revue histo. De droit fr. et Str., 5 (1926) 375; 6 (1927) 195; H. R. Hoetink, Pericultum est emptorist Harlem, 1928; Krickmon, Einige Randfragen ztem periculum emptoris, ZSS. 59 (1939) 1, ZSS 60 (T940) I.; Arangio-Ruiz, Responsabilita contrattuale, 2 nci tab's, Napoli 1933, 8. 147 v. $d_{\text {; }}$ Meylan, Ittra, 1 (1950) 253 v. d.; Meylan, Inst. III, 23, 3 et $3 a$, linification du régime des risques dars le contrat de vente par Justinien. 
B. Pe:iculum est emptoris sahasında ilk büyük nazariyeyi büyük İtalyan Romancsi Arno ilexi sürmüş ve f'kirlerini 1897 den 1910 senesi ne kadar, birbirini takkip eden bir çok yazıda müdafa etmiştir (37). Arnonun fikirlerini 1919 senesinde bir yazısında topliyan ve cok iyj hülasa ettikten sonra daha da öteye götü:en meşhur Alman Hukukçusu Franz Haymann (38) olmuştur. Arno ve Haymann'1n fikirleri şu şekilde hülâsa edilebilir: Klasik Roma Hukukunda, mebiin teslimine kadar hasar bâyie aitti. Ancak teslimden sonra hasar müşteriye-intikal etmiştir. Her indi mïellif, bu prensiple ilgili metinglerin klassik hukukçulara ait olmadiklarını, olamıyacaklarıı ispat etmeğe çalı̧mışlar, Interpolatio'lan göster meğe gayret etmişler ve itíraf etmek lazım ki 1928-1930 seneleri civarinda fikírlerinin doğ:u olduğu hakknda umumt bir kanaat yaratmı̧lardır. Interpolatio araştırmalarının, zirvesịni ve aynı zamanda bir az da dönüm noktasını teşkil eden bu senelerde Haymann'in tezi büyük bir tesir yap miştır. Bi]hassa mukni görünen tarafi Periculum est empto:is kaidesi ile uzlaşamıyan diğer metinlerdi. Ancak çok geçmeden Arno ve Haymann'ın fikirlerine karșı itirazlar yuiksseldi. Burada bütün teferruatı ile inceliye. mijyeceğimiz tenkitler'n umumi hatları şöyle bülâsa edilebiliv: Arno ve Haymann'ın Periculum est emptoris prensibiyle bağdaşamıyan metin ola. rak gösterdiğ metinlerin, ezciumle D. 18, 6, 13; D. 18, 6, 14; D. 18, 6, 15; D. 19,2, 33 ün sadece esas prensibinin istisnası olduğu gö.tîlmüştü. Zirra bu metinler asıl prensibi kayıtsız şartsız bertaraf etmiyen, isțisnaî mahiyette metinlerdi. Bunla: belki Periculum est emptoris kaidesini dolaylsiyle tahdit ediyorlardi. Fakat bu tahdidin prensibi bertaraf edecek ka. dar ileri gitmediłgi mubakkaktı. Diğer taraftan kanaatımızca Armo ve Haymann'in iddialarndaki zayuf taraf yukarda zikrettigimiz metinle:in klâsik olduklar hakkkında mukni deliller göstermemelerindedir. Hasar

Afti del Coneresso internazionale di disiteo romano. Verona 1948 (1953 sonouindo bandmatar) c. III \&. 387 v. d.

(34) Jörs, Binkmeyers Encyldopedie. 133, 69, s. 1442 b a.

(35) Jow - Kunkel . Wenger, Römincher Reche 2 ,oe 3 netl wab 141, 2, S. 228. D229.

(36) Beweler, Romaniatioche Studien, Tildachrift por Rechageschidenth 8 (1928) *. 278 o. $d$.

(37) Anno, La ceovis del periculum nei wenditae nel diritto romono claseico,

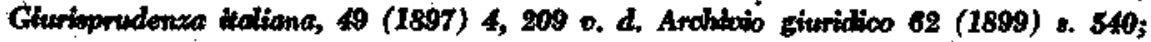
65 (1900) \&. 301 o. d, 68 (1902) 8. 429 o. d.; Studi in onore di v. Saialoia, c. I 2. 343 v. d.; Málange Fiutine, cll 1 s. 29 v. d.; Memonie dell'Accodemia di Modena, wi If. c. 9 (1208); Studi in onone di B. Bruge (1910) s. 153.

(38) Hayman, Textkrititche Studten ztem womisohen Obligationennecht, ZSS

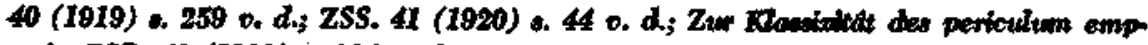
torith, ZSS. 48 (1928) i. 314 v. d. 
prensibibini ithtiva eden metinlerin klâsik olmadığın, interpolatio gördüklerini iddia eden müellifler ona aykırı olan metinle: in klâsik olduğunu kabul ediyor. Belki dedikleri, «িspat edilebïlirse, doğrndur. Fakai aykırı metinlerin klâsik olduğu hakkındaki delilleri zayıf kalıyor, tat min etmiyor. Arno ve Haymann'n fiki: Ieni arasinda zayaf kalan diğer bír nokta da Iustinianus Hukukuna Periculum est emptoris kaidesinin nasIl int.kal ettiğini izah edememeleridir. Halbuki onun klâsik hukuktaki mevcudiryeti, peşin para le yapllan satıştan arta kalan son hüküm şeklinde kabulüne miincer olmaktaydı (39).

Arno ve bilhassa Haymann, karşllkll edalar ihtiva eden akitlerde. malla:n mübadelesinden hareket eden Romallarin, semene ancak mebiin tesliminden sonra istihkak kesbedileceğini bona fides'e dayanan bu prensibin gerekli defìyi de temin edeceğini ileri sürmüşlerdir (40). Ancak biz bona fides kaidesinin Roma'da ne kadar geç inkişaf ettègini biliyoruz. Mülkiyette zilyetlikte bu prensibe o zaman belki varlmamıs ofması karşısında (4I) Roma Hukukumun, bon ${ }_{a}$ fdesì hịç bä: zaman umumî ve mutlak bir kaide haline getirmediğgi kanaatını bile verit. Bunun yanında karş̧lıklı edalarda ileri sürelecek defiler (B. K. 210 mânasında) meveut metinle: karşısında daha çok klâsik hukukun bir buluşu gỉ̄i tezahür etmektedir.

Bu gün Arno ve Haymann'n fiki-leri artık pek taraftar bulamamaktadir. Prof. Schwarz'n dediği gibi muhtemelen Haymann'in esas tezi yanlıştır (42). Yeni ders kitaplannda Haymann'in fikrine iltihak eden müellife artık rastlanmamaktadrr.

C. Haymann'ın tezine karşı ilk itirazları yapan Rabel (43) olmuş, Haymann'ın delillerini mukni bulmamıs, bilhassa metinlerin a:asında klâsik hukuktan gelenlerin bulunduğu jddiasına itiraz etmiş ve kendisı daha ilenti giderek, Periculum est emptoris kaidesinin klâs'k hukukta bir kaide olmadığgl, karşımıza çıkan metinlerde hususî vak'alar iç̧in, verils: mọş mütalâxlardan ỉbaret olduğu, umumî hüküm gibi görünen metinlerde ise Bizanslıların Interpolatio'ları iłe karşılaştığımız, muhtemelen bu umumî hüküm mahyetindeki - metinlerdeki hâdisele in Tribonianus hey'eti tarafından tay edildiği fiakrini ortaya atmıs ve netice itibarayle Klâsiḳ Hukukta böyle bir «p:ensibin " hiç bör zaman mevcut olma-

(39) Buma benxigen Crastodia mestulifreti için yudarda Ve bakmuz.

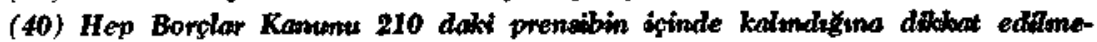
lidis.

(41) Bona fides'in Roma Huktukendaki inkigaft igin Ziqu Umer, Roma Huktukton-

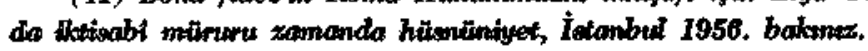

(42) Schwovarz, a, g. yaxz c. 164.

(43) Rabel, ZSS 42 (1922) 543 o. d, oe Gefahrtragtung bein Kauf, ZSS 47 (1927) ร. 117 v. $d$. 
dığmı iddia etmiştir. Kendi ifadesi ile colsa olsa ticari bir teamül idis.

Bu fikir taraftar bulmuştur (44). Ancak dikkat edilirse problemi hal etmityen bir buluştur. Zira kanaatımızca, klâsiłk hukukçula:in bị çok hal lerde, - bu istisnaî hallerin ne kadar cok ve değisik olduğunu bize Corpus furis Civilis kâfi sarahatla gösteriyor - Periculum est emptorís'e gidilmesi, bu hükmün icabi halde müracaat edilen, elde mevcut bir prensibin alametídir. Kaldı ki Klâsik Hukukçularm buna müracaat ettikkderi hallerin çokluğu göz önünde tutulursa prensibin mevcut ol madığı, icabı häle göre tatbilk edildiği iddiası bir az zayif. kalmaktadır. Vakıa bu tenkitteki tehlikeyi gören Rabel klâsiłk zannedillen bìr çok metinlerin kiâs'ik olmadı̆̆m göstermeğge çalışmıştır. Bu interpolatio şüpheleri ise çok münakaşa edilmiş olup kat’î bir fikir ve:ememişlerdir.

Diğer taraftan bu nazariyeye göre klâsik hukukçuların bu sahada sarih bir fikkre sahip olmadıklannı kabul etmek icap ediyor ki çok şüphe ile karşılanacak bir fikirdir (45).

D. Haymann'in nazariyesinden sonra en derin tesiri yapan tanınmịs Alman Rơma Hukukçusu Seckel ile onun talebesi $E$ :nst Levy olmustur. Seckel bu mevzuda hazrladığ etraflı bü* tetkiki neşrederneden ölmüştï. Bu tetkjki bàr daha gözden geciren ve hocasınin, çok iyi bildiłg fikirlerine göre işleyip tamamlyyan Levy, yazıyı 1927 senesinde müşte. rek isim altında neşretti (46).

Seckel - Levy'e göre «Pexiculưm est emptoris» kaidesi klâsik hu kukta her halde vard, fakat cok tahdit edilmisti. Her şeyden evvel satı̧̧ı perfecta olması låzmmdı. Hukukçu Paulus perfecta satışn ne alduğunu D. 18, 6, 8 pr. de izah etmiştir. Bu metin mühim interpolatio'lar görmüştür (47). Buna rağmen 'perfecta est emptios'ya kada: olan yeri umumî kanaata göre klâsijk olduğundan ihticaca salihttir. Seckel - Levy per fecta satışın, ancak mebian teslimi ve tesellüme salith olması anında mev. zubahis olduğunu ileri sürmüşlerdir. Custodia mes'uliyetínin bulunduğgu hallerde de epericulum est emptoris» tatbilk edilemezdi (48). Bir de istimlâk gïbi, devlet tarafından mebilin alınması halinde de periculum est emptoris»e yer verilmediğ görülüyor (D. 19, 2, 33 ve D. 21, 2, $11 \mathrm{pr}$ (49)).

Tatbik sahast bu kadar daraltilan epericulum est emptorisede kala kala peşin para ile yapılan satış akitlerini ve maddesi itibathyle çok ko

(44) Sieber, Römiaches Rocht. c. II ^. 197'e bakentz.

(45) Jörs - Kunitel - Wenter, a. g. 6. 141 \&, 228 not 6 'a da bakmat.

(46) Seckel-Leog, ZSS. 47, s. 117 o.d.

(47) Index interpolationem de c. I s. 334 D. 18, 6, 8 pre balonez.

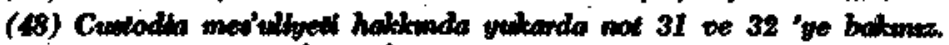

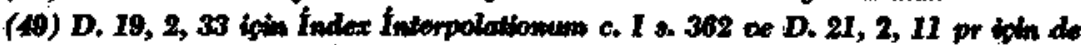
Index Interpolationam c. $I$ s. 14 bakwaxt. 
lay bozulan mallan görüyoruz. Kolay bozulan mallayda bile spericulum est emptoris»in tatbrikatında bir tahdit müşahede etmek mümkün: Şarap satı̧̧inda kullanılan eQuod neque aceat neque muceat, id dabitur formülü (Cato. De agricultura 148,3) periculum est emptoris'den ayrl. manın bir deliliklir. Nev'en muayyen mallar da tabil tatbik sahası dışında kaliyo:.

Seckel - Levy'nin nazariyesti çok taraftar bulmus olmakla beraber, (60) emptio perfecta hakkandaki fikirleri yanlış ad edilmiştir (51). Saniyen prensibin tatbikkinde geriye kalan mahdut saha, bunun klasik hukukta blr prensip olup olamdığı hakknda şüphe vermektedir. Bu şŭphe karşısında Rabel'in telakkisinin daha doğ vu olup olmadiğı cai sual olu yor.

1930 senesinden sonra Roma hukukunda hasann intilkali hakkındaki münakaşaların kesildiğini görüyoruz. Yavaş yavaş bu mevza ile ilgili hiç bir şey neşredilmez oluyor. Bu Prof. Schwarz'm dediği gibi, bazı müßs. küllerin hal edilmemesi ve bazi suallere cevap bulunamamasindan ilerl geliyor. Pexiculum hakkundaki kaynaklarn son derece mahdut olmasi, (Corpus furis Civilis dışında yalnız Frag. Vatt.c. 16 da bir metin var), ele gegen vesikalarda ve akitlerde kullanıłmamış olması, bir çok metinlerdeki hükiülerin tenakus teşkil etmesi, tetkiklenin ilerlemesine mâni ofmuştur.

VII. 1954 senesinde, Roma Üniversitesi Roma Hukuku Profesö:ü olan Emilio Bettinin aPericulum. Problema del risohio contrattuale in diritto romano classico e giustinianeo isimli uzun yazısı (52) ile mesele yeniden ve bu defa başka bir görüş altında canland1. Kanaatımızca meseleye tatmin edici bir hal çaresil bulan ve memleketimizdeki Roma Huku ku ders k'taplarında daha yer bulmamıs olan Betti”nin fikirle:i şöyle hï LAsa edilebilir:

Profesör Betti her şeyden ovvel bu güne kadar problemin tetkikinde kafi sarih bir hareket noktasına ehemmiyet verilmediğine işaret etmekle żahatina başlıyor ve birbirinden dkkatle ay:ılması gereken dort değişiłk vaziyete işaret ediyor:

a) Borcun mahiyetinden doğan mes'uliyetler (Para borçlannda olduğu gibi mes'uliyet borcun mahiyetine göre değişebilir.)

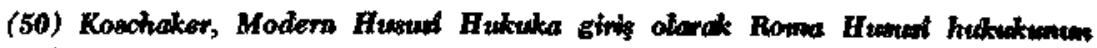
ana hatiar. Ankane 1050 \&. 208 oe 209 bakmuz.

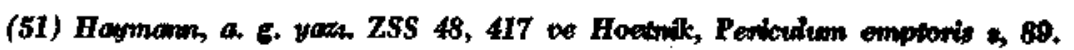

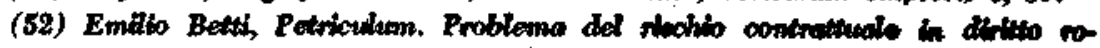

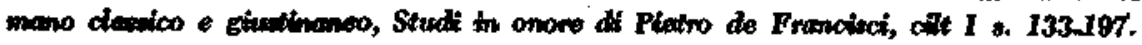


b) Bu mes'uliyetin genişletilmesi hakkłunda yapılan anlaşmalardan doğan, mes'uliyetin deruhtesi (Dos'da olduğu gibi.)

c) Bu mes'uliyetin otomatik olarak genişletilmesi (Borçlunun temerrüdüinde olduğu gibi).

d) Borç münasebetine göre tesbit edilmiş bir riskin akitlero (Hasardan dolayı müşterinin mes'ul ołması gibi) tahmili.

Mantik bir stra altına sokulmak istenirse:

1 - Borcun mahiyetinden doğan mes'ulyet,

2 - Anlaşma gereğince genişletilen, derubte edilen mes'uliyet,

3 - Mora debitoris sebebiyle doğan mes'uliyet,

şeklinde sıralanmaları daha doğru olu:

Borcun mahiyetinden doğan mes'uliyet, aktin yerine getirilmemes sebebiyle ne kadar genişletilirse, riskin derubtesi hakkkında saha o kadar daralır. Roma Hukuku kaynaklan içinde bu ikil türlï mes'uliyet Bizans Hukukçuları tarafından çok ker:e bir birina karıştınlmıştır.

Corpus Iuris Civilis içinde bir çok metin aslında borç münasebeti ittibariyle mes'ul'yetin deruhtesini icab ettirmiyen fakat borcun yerine getirilmemesinden doğan mes'uliyetin bususł bir anlaşma ile genişletildiği hallerdir. Bunlar ballhassa custodia igin mes'ul'yetin ihdas editdiğgi hallerdix. Aslında burada aktin mahiyetinden doğan (à gerejince) mes'uliyet nihayet pater familias'dan taleb edilen dilingentifa kadar idi Betti'nin (53) kanaatına göre satnonnm costodia iç̣in mes'uliyeti de menşe itibariyle aktî̉ir. Klâsik hukukta aktî olan bu mes'uliyet fustîni. anus Hukukunda Kanundan doğan bir mes'uliyet thalini almiştır. Custodiam suscipere veya recipere'den bahsẹden bis çok metinler bu durumu sarahaten belirtmektedir. Inst. $3,23,3$ ve 3 a da metnin aslin da yalnız akti bi: mes'uliyetin bahse konu olduğu esecurus erit» terimin. den ve commodum'da klassik hukukta deruhte edilen periculum'un bítr nevi mukabit ôvazs ad edilmesinden anlaşlıyor. Klâsikten son:aki hukukta ashnda kazuistik olan münferit prensiplerin umumfleştirilmmek istenmesi problemi, gene tetkik konumuzla ilgill başka metinlerde de kendini göstermektedir: D.18,1,35,4: D.19,1,31 pr.; D.47, 2,14 pr. Her üçüinde de custodia için mes'uliyetin, aradaki bir anlaşma gereğince deruhte edildiğinin izleri vardır. Betti çok mukni delillerls bu metinle:deki muhtemel interpolatio'lan belirttikten sonra custodia ile ilgili diğer metinleri de ele alyor ve bahsekonn olan cactio furtis

(53) a. 5. yax o. 139-137. 
deki mes'uliyetin, mevcut bir anlaşma ile deruhte edildiğini gösteriyor (54).

Custodita'dan dolayr mes'vlyyetin hususî bir anlaşmaya istinad etti ğini satış aktinden incelemekle kalmıyan Betti, sırası ile «Locatio rei» (55) - Recepturn (56)'da da ayni durumun bulunduğuna uşaret ediyor, riskin deruhtesi hakkında yapilan, akitte ka:şımıza çlkan bir «aestimatios (kıymet takdirl) sistemine bilhassa dikkati çekiyor. Aestimatio ile ilgili akit lerden *societas» (D. 17,2,52,3'ün tetk'kinde) winstrumentum fundi'nin acs tỉmatio ile kiralanması»n! (D.19,2,3 ve D.19,2,54,2 de karşımıza çıkıor) -dos tesisisni (D.23,3,14 ve D.23,3,15 = D.24,3,9) (57), *comodatums ve satı̧̧ hususunda vekâlet verilen "aestimatio»lu akti (D. 19,3,1,1 ve Paul. Sent. 11,4,4) gösteriyor. Aestimatio ile yaplan bu akitlerde, de:uhte edilen mes'uliyetin, aktin kendisine mahsus olan normal mes'uliyetin hudutlannı aştığı ve anlaşma jle tesbit edilen ayrı bir riskin deruhtesi olduğu çok açıktır.

İustinianus Hukukunda durumun değiştiği görülüyor. Custodia mes'uliyeti kanun tarafindan saticiya tahmil ediliyor dige: taraftan ona muvazi olarak epericulum est emporis» de Corpus Iuris Civilis'in kanunun - hükümleri arasında yer alıyor. Betti, inkişafin bu şekilde olduğunun en kuvvetlì delilini şu noktada buluyor: Klâsìk hukuktaki diligentia, bona fides'in genişletici bir tefsirinden istihraç edilmnişt. Custodia mes'uliyetinin ise mahiyeti itibariyle bona fides ile en ufak bìr alâkası olamazdı. Halbuki Corpus Iuris'in metinlerinde custodianın mucip sebebi olarak bona fides'i görüyoruz. Bunlar aslında diligentia'dan bahseden metinlerdi. (Costodia ise, yukarda zikredilen metinlerde mes'uliyetin bir anlaşma ile deruhte edilmesi idi.) Interpolatio'lan tey' id eden daha kuvvetli emareler de mevcut: metinlerde sik sik adiligentia in custodiendo» ibaresi görülïyor. Bu iki mefhumun bu şekilde bir arada kullanıldığı metinlerden mâna çıkmamaktadır (D. 19, 1, 36; D. 18,6 2,I; D.18,6,3 gibi). Diğer taraftan D.19,2,41 *qua enim custodia consequi potuit» ibaresi custodia'nı bi: akitle deruhte edildiği zamanlardan kal-

(54) Bunada D. 47, 2, 81 (80) pe ve D. 39, 2, 18, 9 da incelentyor. A. 6 , yaut 2. 143 de 144 bakmetr.

(55) 8,145 b) de incelenen motinles D. $19,2,55$ pr.; D. 19, 2, 60, 9; D. 19, 2,$40 ; C, 4,65, I$

(56) a. g. yazt s, $146 \mathrm{c}$ ), de incelenen mainler: D. 4, 9, 5 pr.; D, 4, 9, 1,8 w D. $47,2,14,17$ dir.

(57) D. 23, 3, 14 ve D. 23, 3. 15-D. 24, 3, 9 igin Kudiet Ayter, Kavik Roma

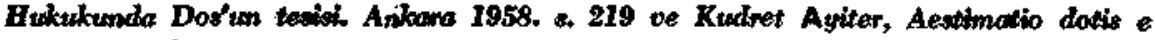

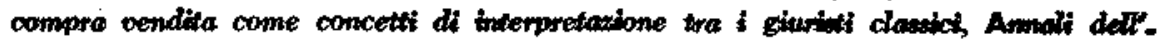
Unieversitè di Ankano (VI, 19541955) s. 143'e bakmz. 
madı: Aynı şekilde D. 19, 2, 36 nın ikinci kısmı da o devirlerden kalma,. değişmemiş bir metin örnegidir.

Periculum est emptoris bahsinde ayni genişletici tefsiri Bizans $\mathrm{Hu}^{-}$ kukçular, Corpus İurís'e ithal ettikleri kemptio perfecta» fikrine muvazi ola :ak yapmışlardır. Commodum repraesentationis de Corpus Iuris'te deruhte edilen hasann bir ivaz1 gibidir. D.18,6,14 (13) ve D.18,4,21 bütün bu temayülleri aksettirmektedir. D.18,6,7 pr. deki *periculumsun aslında sincommodum» olması ihtimali de çok calibi dikkattir (58).

Periculum est emptoris şeklindeki bu yeni prensip xperfectio emp tioniss le ahenk halindedir. Emptio perfecta'yl tanımıyan ve traditio' nun yapıldığı andan sonrası için periculum est emptoris'i kabul eden. Klâsik hukuk bütün bu mes'uliryet sistemine yabancidır. Klâsił roma hukukunda satım aktinin consensual ve aborç akti = taahhüt muamelesis olduğunu Yunan ve Yakın Şark hukukunda ise alienatio'ya miincer bir akit olduğunu unutmamak lâzımdir. Burada da Yunan ve Yakın şark hukukunun Bizans Hukukuna tesiri sarithtir. Ancak Tabonianus'un komisyonu, tamamen Yunan hukukuna iltihak etmemekle ikisi ortası bir hal tarzı bulmıya çalışmışlar yalnız traditio'nun yapılması halinde mâna ifade edecek olan periculum est emptoris'i taahlä̈t muamelesi olan sathşa tatbik etmişlerdir.

Betti, riskin de:uhte edildiği akitlerin mahiyetini de tahlil etmiş tir (59). Riskkin deruhtesi hakkında akitlerin Roma'da yapıldığını ilk defa bu şumulï ile ortaya koyan Betti’dir. Bu problemí incelerken, aktin. bizatihi' kendisinden neş'et eden mas'uliyeti evvelâ sarih bir şekilde hudutlandırıyor. Hukukî muamelenin kendisinden doğan mes'uliyet, borçların mahiyetine göre değişir. Ka:şłlklı iłi edanın mübadelesi şeklindeki synallagmatic akitlerde hasardan dolayı mes'uliyetin bir taraftan diğer tarafa intikali eda mevzuumun diğer tarafın emrine âmade tutulması veya diğer tarafra kontrol edileboilerek vaziyete gelmesiyle olur. Aradaki anlaşmantn kperfectio» olması ile intikal etmez. Mübadole edilen edalar burr eşya değil de bár eşyadan istifade ise, Jocatio rei'de olduğu gibji, res veya operae'nin conducto:'un emrine amade tutulması hasardan dolayı mes'uliyetin int'kalini temin eder. Şirket akti giliri hukukî mùamelelerde ise hasar bakımından mühim olan sual şudur : hangi andan itibaren ayın societas'a dahil olmuştur, hangi andan itiba:en hasar onu veren şahıstan, topluluğa intikal eder? Roma Hukukuna göre aynın topluluğa tahsisi veya hasarın toplulügun faaliyetinden neş'et etmesi hallerinde hasar topluluğa ait olurdu. Nühayet bir işin yapılması ile

(58) Betti, a, g. yase 8. 161 .

(59) Betti, a. g. youk. t. 169 v. d. 
ilgili akitlerde (ezcümle Mandatum'da) is sahibi lehine yaplan, onun menfaatine olan işlerde hasar iş sahibine intikal ederdi (60).

Hususu ile satım aktinde, klâsilk hukukta hasa: traditio ile intikal ediyordu. Traditio'ya kadar veya mebiin müşterinin emrine amade tutulmasına kadar hasar saticiya, bu muamelelerin yapumasindan sonra ise müşteriye aft oluyordu. Şu kadar ki eğer małn mahiyeti hasarın daha evvel müşteriye geçmesini icab ettiniyorsa veya satıc hasar husust bir akitle üzerine almß̧sa o vakit bu umumî kaide değjşyordu. Betti bir çok metinlerde bu durumu tetkiik edìyor: D. 19,2,33; D. 18,6,13 ilâ 17; D. 18,6,17 pr. Bu arada bilhassa hasarın müşteriłye daha evvel intikadi net:cesinit tevlit eden halleri inceliyor:

a) Res üzerinde müştetinnin bir kontrol haikkını elde etmesi.

b) Çok kolay bozulabilen mallarda müşterinin malı kontrol etmiş -olması. Şarap alım satımlarında degustatio.

c) Ölmesi ihtimali bulunan kölenin alım satımında hasarın müşteriye geçmesi. Bilhassa bu son hal hasarin Roma Hukukunda yalniz ve yalnı traditio ile geçtiginin en kat'i delilini veriyor. Zira bu duruma ait D.18, 5,5,2 de kölenin alım satımında t:aditio ile jlgili hiç bir husus bulunmadığı halde hasarın geçmesi traditio esbabı mucibesine bağ laniyor ve hasar *traditio yapulmışcasına müşteriye intikal ediyor.

d) Satın alınan kölenín satıcı nezdinde bırakılıması, orada müşterinin nef'ine çalıştırılması veya tohlikeli bir işte çalıştırılması halinde hasarın müşteriye ait olacağ çok tabiidir.

e) Emptio in aversione ve emptio in diem addictio. hallerinde de hasarın müşteriye intikali tabî karşılanabilir. D.18,1, 62,2 ve D.18,2,3. bu şekilde bir çok malın hep bir arada götürü bir fiyatla satın alındığ hallerden bahsediyor.

Netice itibariyle, hasarn intikali esas itibariyle traditio ile cereyan etmekte fakat aktin mahiyeti riskin bir tarafa ait olmasin $n_{1}$ icab ettiriyorsa o taraf riski deruhte etmiş sayilmaktadır.

Ayni durum diğer akit tiplerinde de tezahür ediyor.

Locatio operis'de esas tibariyle satışıda gördüğümüz esaslar tat bik ediliyor. Hasa", işin yapılmasına kadar conductor operis'e aitken, sonra Iocator operis'e geçiyor. Opus bittikten sonra conductor onu lo-

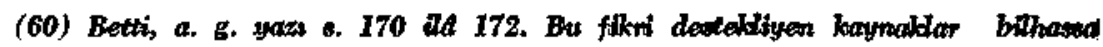
D. $19,2,19,3 ;$ D. 19, 2,38 pr.s D. 17, 2, 58 pr. Ayrica Wieacker, Ceseldechaftuentrag. ZSS 69 (1952) \&. 325 bakmat. 
cator'a tasvibi: igin arz eder, tavsib edilince (adprobatio) hasar locator'a geçer. (D.19,2, 36 ve D.19.2,37 de bu bakımdan yapulmuş olan inter polatio'ları Betti izah ediyo: (61). Betti burada, ayni bahse giren, nakliye mukavelesini ve gemicilerin nakliye mukavelelerini de inç̣liyor ve. muvazi neticelere variyor.

Betti'nin Klâsik Hukuk íçin ileri sürdükleri, bazı akitlerin değişme den hustinianus. Hukukuna kada: intikal etmeleni ile de tey'it edilmiştir. Ísimsiz real kont."aktlar, locatio rei, locatio operarum, societas mandatum hepsi hasar bakımından klâsik hukuktaki asli şekillerini muhafaza etmişlerdir (62).

VIII. Periculum est emptoris sahasında Betti'ye kada: lleri sürïlen diğer nazariyeler problemle ilgili bütün metinleri ̣özememiş, hepsini - interpolatio izahlarına rağmen - bir ahenk içinde izah edememişti. Bettỉnin ileri sürdügui fikirde en kuvvetli taraf bu gäne kadar yaplldığ gîbi yalnız satıs aktinde vaztyetin incelenmesi ile iktifa edil. mem/ş, problem, bütün akitlere teşmil edł̈lmiş ve bütün akit tipieri iựin Klâsik Roma Hukuku'nda müş̧terek bịr hal tarzı aranmış olmasıdır. Vakıa biz, Klâsijk Rema Hukukçularının müşterek, umumî p:ensipler aramadiklarm, çok kere münferit akitler iģin mütenakıs görünen hükümler tatbik ettiklerini biliyoruz. Fakat «Umumi Hüküm» ismi altında toplanmasa bile, bir devrin hukukçularınmn hiç olmazsa müş̧terek veya yakın bir hukuk mantığ ile hareket ettikleri dogrrudur. Betti bu vakıay "periculum* bahsinde çok iyi göstermiştir. Bütün akit tipleri için bulduğu müşterek hüküm esas itibariyle periculum'un borç̧iuya ait olduğu, custodia mes'uliyetinin hususî bir anlaşma ile deruhte edildiğg, periculum dan dolayı mes'uliyetin alacaklıya geçmesi için aktin mahiyetino ve menfaatler'durumuna göre bunưn kabul edilmis olması icab ettiği anlaşlliyor.

He: halde «Periculum est emptoris» diye umumî bìr hüküm Klầ sik Roma Hukukunda yoktu. Bu bakımdan Roma Hukukçularınin bu garib prensibe nasıl, niçin geldikleri hakkında bir izah tarzı aramak beyhudedir. Iustinianus Hukukundaki deģişme, kazuistik Roma Hukuku. nun malzemesini bir kanunun maddeleri serisi haline getirilmesi ve bu arada yapilması gereken interpolatio'la:ın yapılmasına, traditio ile intikal eden periculum'da farazî teslimlerin kabulü sebebiyle periculum'. un intikalinin daha önceye almmasına, Custodia mes'uliyetinln, peri-

(61) Ads gecen yazt. 5. 186 ve 187. Bu arada Betfi İulinianus Hukuktonda кopusso mefhumuntun nasul değiģtiğini de gösteriyor.

(62) Incelemen metinler s. 190 da D. 12, 4, 16 s. 191 de C. 4, 6, 10; D. 12, 4, 5 pr.; D. 12, 4, 3, 3; D. 19, 5, 5, I; ve s. 192 de D. $19,2,15,2$. 
culum'a muvazi olarak her hal ve şartta var farz edilmesine, krediye dayanan muamelelerinin a:tmasına ve bu yeni' durumda satılmış olan mebiin bedelinin talep hakkı çok sağlam olduğundan daha tahsil edile memiş olan bu meblağ üzerinden de kredinin temin edilmesine ve ni. hayet Yunan Hukukunda satı̧ aktinde mïlkyetin hemen intikal etmesi prensibinin Iustinianus Hukukuna tesir etmiş olmasına hamledilebilir, ve bu şekillde izah edilebilitr. Yukarda da işaret ettiğimiz gibi Iustinianus devrinin hukukçuları, Yunan Hukukunun tesiri altında idiler. Fakat mülkiyetin satış akți ile doğrudan doğruya geçeceğinài jfade edememişler dir. $\mathrm{Bu}$, yeniden canlandırlmakta olan, veya canland $d_{1: 1 m a k}$ istenen Klàsik Roma Hukukunun taahhüt-tasarruf muameleleri sistemine (63) çok fazla aykırı düșerdi. Yalnız hasarın aktin in'ïkadı ile geçeceğini ileri sürdüler. Fakat metinlerdeki değişiklik eski durumun görülmesine mâni olmuyor.

IX. Roma Hukukunda Periculum est emptoris'in duzumunu şu sekilde bir araya toplyabiliriz: Hasar teslimle intikal ediyor. Teslim anına kadar satıcını, teslimden sonra jse müşterinindir. Satıcı eğer muhafazayı tekeffül etmişse veya müşteri' mal üzerinde kontrò imkânın ${ }_{\downarrow}$ elde etmişse o zaman hasa: miissteriye intikal eder. Buna bir de müşterinin temerrïdünü ilâve edebiliriz.

Profesör Schwarz'in 1948 senesinde, açılmasinı temenni ettið̣̌: müna. kaşa bakımından da şunu ilâve etmek yerinde olacak : Prof. Schwarz Borçlar Kanunumuzdaki hükmiun kullanıssız olduğunu ileri sürmüştü. Kullanışsız olduğunu Roma Hukuku ile, menşei ile, tey'id edebiliriz. Kanunumuz, hukuk mantığına aykırı bir tanzim tarzını ifade ediyor. Bu tanzim tarzının Bizans Hukukunda ne kadar yanlıs temellere dayandırı̄dığını göstermekle aynı şey bizim Borçla: Kanunu için de yapılmış oluyor. Bíz, vakıa Klâsik Roma Hukuku kaynaklammın - Bizanslılarda olduğu gibi - kanun vazı tarafından yanlış anlaşıldığını ileri sürerek mevcut hïkmü tenkit edemeyiz. Fakat Mukayeseli Hukuk yolu ile başka hukuklardaki du:umu göstererek bir hal çaresinin bulunmasına yardim edebiliriz.

(63) Roma Hukukunda bu terimlerin meocu olmamast tasnifin fitlen bultomma mast demek değildi. Kudret Ayiter, Medent Bukubta tasarruf muamelelent. Ankara 7953. \&. baktnzt. 